\title{
Epidemiological data and a score-based study of renal, hepatic and cerebral lesions in feline infectious peritonitis
}

\section{Dados epidemiológicos e estudo baseado em escore de lesões renais, hepáticas e cerebrais na peritonite infecciosa felina}

\author{
Thalita Evani Silva de Oliveira'; Giovana Wingeter Di Santis²; \\ Selwyn Arlington Headley ${ }^{2 *}$
}

\begin{abstract}
The study describes the epidemiological and pathological findings observed in a population of cats with feline infectious peritonitis (FIP) and estimated the degree of tissue destruction in the kidney, brain, and liver. A retrospective study was performed to determine the number of cats with a histopathological diagnosis of FIP between 2005-2016, at the Laboratory of Animal Pathology, Universidade Estadual de Londrina. The histopathological alterations in selected organs (brain, liver and kidneys) associated with FIP were described and then compared with a scoring system to estimate the degree of tissue destruction. FIP was diagnosed in 3.7\% (19/520) of all cats necropsied during the 11-year period; sexual and breed predominance were not identified. Cats that were less than one-year-old were more frequently diagnosed with FIP. Pyogranulomatous nephritis with vasculitis $(94.7 \%$; 18/19), coagulative renal necrosis $(84.2 \% ; 16 / 19)$, hepatocellular necrosis $(57.9 ; 11 / 19)$, and necrotizing leptomeningitis $(47.4 \%$; 9/19) were the most frequent lesions observed. Moreover, FIP-associated renal lesions were more severe and frequently observed when compared with those in the brain and liver. It is proposed that necrosis be considered as an important lesion associated with FIP that should be included in the histopathological diagnosis of this disease.
\end{abstract}

Key words: Coagulative necrosis. Feline. Histopathology. Lesional score. Pyogranulomas. Vasculitis.

\section{Resumo}

Este estudo descreve os achados epidemiológicos e patológicos observados em uma população de gatos com peritonite infecciosa felina (PIF) e mensurou o grau de lesão tecidual no rim, cérebro e fígado. Realizou-se um estudo retrospectivo para determinar o número de gatos com diagnóstico histopatológico de PIF entre 2005-2016, no Laboratório de Patologia Animal, na Universidade Estadual de Londrina. As alterações histopatológicas associadas à PIF em órgãos selecionados (cérebro, fígado e rins) foram descritas e comparadas com um sistema de pontuação para estimar o grau de lesão tecidual. A PIF foi diagnosticada em 3,7\% (19/520) de todos os gatos necropsiados durante o período de 11 anos. Não houve diferença estatística para sexo e raça. Gatos que tinham menos de um ano de idade foram frequentemente diagnosticados com PIF. As lesões mais frequentes observadas foram nefrite piogranulomatosa com vasculite $(94,7 \% ; 18 / 19)$, necrose renal coagulante $(84,2 \%, 16 / 19)$, necrose hepatocelular $(57,9 \% ; 11)$ e leptomeningite necrotizante $(47,9 \% ; 9 / 19)$. Além disso, as lesões renais associadas ao PIF foram mais graves e frequentes quando comparadas com as do cérebro e fígado. Propõe-se que a necrose seja considerada como uma importante lesão associada a PIF que deve ser incluída no diagnóstico histopatológico desta doença.

Palavras-chave: Necrose coagulativa. Felino. Escore lesional. Histopatologia. Piogranulomas. Vasculite.

\footnotetext{
${ }^{1}$ Discente, Programa de Pós-Graduação em Ciência Animal, Universidade Estadual de Londrina, UEL, Londrina, PR, Brasil. E-mail: thalitamvet@gmail.com

2 Profs. Drs., Departamento de Medicina Veterinária Preventiva, UEL, Londrina, PR, Brasil. E-mail: giovanaws@uel.br; selwyn. headleysa@uel.br

* Author for correspondence
} 


\section{Introduction}

Feline infectious peritonitis (FIP) is a progressive and fatal disease of cats caused by the virulent feline coronavirus variant (FCoVs), named feline infectious peritonitis virus, FIPV (PEDERSEN, 2009). FIP has been reported predominantly in cats that are less than two years of age (ADDIE et al., 2009; PEDERSEN, 2009; ADDIE, 2012; RIEMER et al., 2016), due to the immature immune systems of these animals (HARTMANN, 2005; ADDIE et al., 2009; PEDERSEN, 2009).

Epidemiological studies of FIP have been reported from different countries, demonstrating that cats with less one-year-old and cats living in shelters are more predisposed to contracting FIP, including Australia (NORRIS et al., 2005; BELL et al., 2006; WORTHING et al., 2012), Austria (BENETKA et al., 2004), Brazil (OLIVEIRA et al., 2003; SANTOS et al., 2013), Japan (TANAKA et al., 2015), Turkey (TEKELIOGLU et al., 2015), USA (HARTMANN, 2005; PESTEANU-SOMOGYI et al., 2006; PEDERSEN, 2009), and Germany (RIEMER et al., 2016). However, none of these have investigated the degree of tissue destruction associated with FIP.

There is little information relative to the epidemiology of FIP in Brazil, with studies based predominantly on disease prevalence (OLIVEIRA et al., 2003; SANTOS et al., 2013). This study describes the epidemiological data and pathological findings observed in a population of cats with FIP, and estimated the degree of tissue destruction in organs frequently affected in this disease.

\section{Materials and Methods}

\section{Study location and cats}

A retrospective study was performed to determine the number of cats necropsied at the Laboratory of Animal Pathology, Universidade Estadual de Londrina (LAP/UEL), Paraná, Southern Brazil from January 2005 to December 2016 with a histopathological diagnosis of FIP. A total of 520 cats were studied, most part of them $(n=485)$ necropsied originated from the Veterinary Teaching Hospital (VTH/UEL); and the others $(n=35)$ were submitted by private veterinarians or owners for a complete necropsy.

Information relative to the medical history, breed, gender, age, type of FIP, gross lesions, and morphological histopathological diagnoses were recovered from necropsy reports, tabulated, and analyzed. The disease was classified as effusive and non-effusive due to the presence or absence of free liquids within natural cavities. When necessary, histopathological slides were prepared from the archives of LAP/UEL.

\section{Pathological data and lesional score}

A diagnosis of FIP was made by a combination of the necropsy findings and histopathological alterations described in the necropsy report of each animal. All cases with a diagnosis of FIP were reviewed to evaluate the organs affected and the extension of the lesion in each. Morphological diagnoses were considered only from three organs (kidneys, liver, and brain), since these were most frequently affected and present in all cats evaluated. Due to the retrospective character of the study, only samples contained in paraffin blocks were used during this evaluation.

The histopathological alterations were grouped based on morphological diagnoses associated with FIP and then compared with a previously used scoring system (GRENIER et al., 2011), with adaptations. Briefly, the lesional score was calculated by considering the degree of severity (severity factor) and the extension of each lesion (per intensity, scored from 0 to 3 ) in the affected organ (Table 1). The organ score was then obtained by the sum of each lesional score. The severity factor was defined as mild (1), moderate (2), and severe (3); the intensity of each lesion was evaluated and scored as no lesion (0), minimal (1), intermediate (2), and 
extensive (3). For the organs evaluated (kidney, brain, and liver), for each lesion, the score of the extension was multiplied by the severity factor, the minimal score was 0 and the maximum attainable scores were 48.

Table 1. The lesional score used to determine the intensity of lesions in cats with FIP.

\begin{tabular}{llr}
\hline Organs evaluated & \multicolumn{1}{c}{ Type of lesions (severity factor) } & Maximal score \\
\hline Kidney & Tubular degeneration (1) & \\
& Inflammatory infiltrate (2) & \\
& Proteinosis (2) & \\
& Vasculitis (2) \\
& Membranous glomerulonephritis (3) & \\
& Necrosis (3) & \\
& Thrombosis (3) \\
& Cholestasis (1) \\
& Vacuolar degeneration (1) \\
& Fibrosis (2) \\
Liver & Inflammatory infiltrate (2) \\
& Vasculitis (2) \\
& Necrosis (3) \\
& Thrombosis (3) \\
& Congestion (1) \\
& White matter vacuolization (2) \\
& Perivascular cuffing (2) \\
Vasculitis (2) & Inflammatory infiltrate in leptomeninges (3) \\
Necrosis of the meninges (3) \\
Thrombosis (3) \\
\end{tabular}

\section{Statistical analyses}

Nonparametric variables (qualitative data) such as frequencies and percentages were analyzed as descriptive statistics. Cats were divided into two predefined age-related groups: those that were less than and more than one year of age, based on the incidence of this disease (HARTMANN, 2005; ADDIE et al., 2009; PEDERSEN, 2009; SOMA et al., 2013; RIEMER et al., 2016). Clinical variables (gender and breed) related to the age of cats with FIP were determined by using the Chi Square test $(P \leq 0.05)$, by univariate analysis.

Data for the scores used were presented as means and standard errors, and were statistically analysed by normality (Shapiro-Wilk) and homogeneity (Bartlett) tests, after the data were box-cox transformation. When these two conditions were attained, the analysis of variance (ANOVA) was applied followed by the Tukey test; $P$-values of $\leq 0.05$ were considered as significant. Statistical analyzes were performed with software Action Stat, version free (São Carlos, SP, Brazil).

\section{Results}

\section{Biological data of cats}

During the period of study, 520 cats were necropsied at the LAP/UEL; however, consistent 
data relative to the gender was provided from 379 cats, while information of the breed and age of cats were available for only 234 animals. During this study, 3.7\% (19/520) of all cats necropsied had a histopathological diagnosis of FIP. There was no statistical difference between the gender (males, 10; females, $9 ; P=0.822)$ and breed $(P=0.437)$ of cats affected. Most cats with FIP were less than oneyear-of-age $\left(14 / 19, P=9 \times 10^{-7}\right)$.

\section{Gross manifestations of FIP}

The main pathological findings are resumed in Figure 1. The effusive form of FIP was predominant, and occurred in $68.4 \%(13 / 19)$ of all cats; noneffusive FIP was observed in $31.6 \%(6 / 19)$ of the cats evaluated. All cats with effusive FIP had serohemorragic peritoneal effusion with fibrin deposition at the serosal surfaces of abdominal organs; pleural effusions were observed only in three cases.

Pyogranulomatous nephritis $(78.9 \% ; 15 / 19)$ was the most frequently observed lesion in cats with FIP. Pyogranulomas (Figure 2) were also observed at serosal surfaces of the liver $(78.9 \% ; 15 / 19)$, the mesentery $(36.8 \% ; 7 / 19)$, eyes $(31.6 \% ; 6 / 19)$, spleen $(26.3 \% ; 5 / 19)$, pulmonary pleura $(26.3 \% ; 5 / 19)$, and cerebral meninges $(15.8 \% ; 3 / 19)$. Pyogranulomas were multifocal to coalescing, 0.1 to $3.0 \mathrm{~cm}$ in diameter, discrete to severe, and white to yellow colored. Renal granulomas were more pronounced around blood vessels.

\section{Histopathological patterns observed in FIP}

In this study, the kidney was the most frequently affected organ, with lesions occurring at the capsular surface that extended into the renal parenchyma. Renal pyogranulomas were multifocal to coalescing and there were extensive areas of vasculitis, fibrinoid degeneration, and thrombosis. In addition, coagulative necrosis was one of the most destructive histopathological alterations observed during this study, being present in the kidney $(84.2 \% ; 16 / 19)$, liver $(57.9 \% ; 11 / 19)$, and brain $(47.4 \%$; $9 / 19)$ of cats with FIP. In most cases, necrosis was perivascular and seemed to have originated from disrupted vessels. However, renal necrosis was comparatively more severe and extensive when compared to this alteration in the liver and brain. In cats with FIP, necrosis resulted in the destruction of more than $40-50 \%$ of the renal parenchyma (Figure 3A). Hepatocellular necrosis was random, predominantly perivascular and result in destruction in approximately $20-30 \%$ of the hepatic parenchyma. Cerebral necrosis was restricted to the leptomeninges and responsible for destruction to $5-10 \%$ of this area.

The principal histopathological lesions observed during this study are shown in Figure 1. Pyogranulomatous nephritis with associated vasculitis was the predominant histopathological diagnosis and occurred in most $(94.7 ; 18 / 19)$ cats necropsied; disseminated vasculitis $(94.7 \% ; 18 / 19)$ affecting multiple organs was also frequently observed. Other frequent histopathological diagnoses included pyogranulomatous hepatitis $(89.5 \% ; 17 / 19)$, renal necrosis and glomerular sclerosis $(84.2 \% ; 16 / 19)$, necrotizing leptomeningitis $(68.4 \% ; 13 / 19)$ and hepatitis $(57.9 \% ; 11 / 19)$, pyogranulomatous meningoencephalitis (47.4\%; 9/19), periesplenitis $(47.4 \% ; 9 / 19)$, pneumonia, enteritis and pleuritis $(42.1 \% ; 8 / 19)$, peritonitis (36.8\%; 7/19), and lymphadenitis $(26.3 \% ; 5 / 19)$. In addition, there were three cases of pyogranulomatous myositis and panophthalmitis 
Figure 1. Graphical demonstration of the distribution of the main gross (A) and histopathological (B) findings observed in cats infected with FIP.

A

Pyogranulomas in the cerebral meninges

Pyogranulomas in the pleura of lungs

Pyogranulomas spleen

Corneal opacity

Pyogranulomas mesentery

Pyogranulomas at serosal surfaces of the liver

Pyogranulomatous nephritis

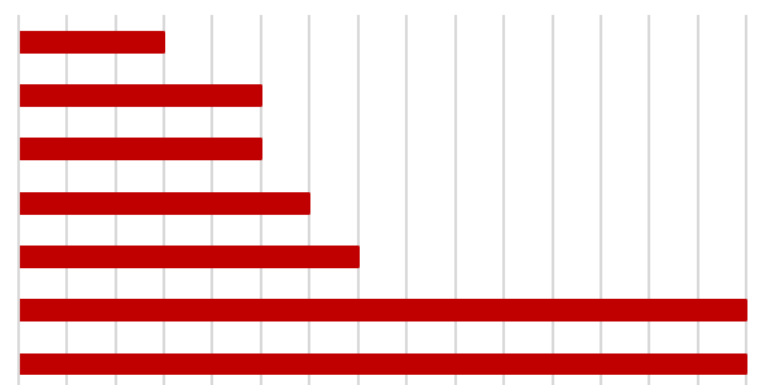

$\begin{array}{lllllllllllllllllll}0 & 1 & 2 & 3 & 4 & 5 & 6 & 7 & 8 & 9 & 10 & 11 & 12 & 13 & 14 & 15 & 16 & 17 & 18\end{array}$ Number of cats affected

B

Pyogranulomatous panophthalmitis

Pyogranulomatous myositis

Pyogranulomatous lymphadenitis

Pyogranulomatous peritonitis

Pyogranulomatous pleuritis

Pyogranulomatous enteritis

Pyogranulomatous pneumonia

Pyogranulomatous periesplenitis

Pyogranulomatous meningoencephalitis

Necrotizing hepatitis

Necrotizing leptomeningitis

Renal necrosis and glomerular sclerosis

Pyogranulomatous hepatitis

Pyogranulomatous nephritis with vasculitis

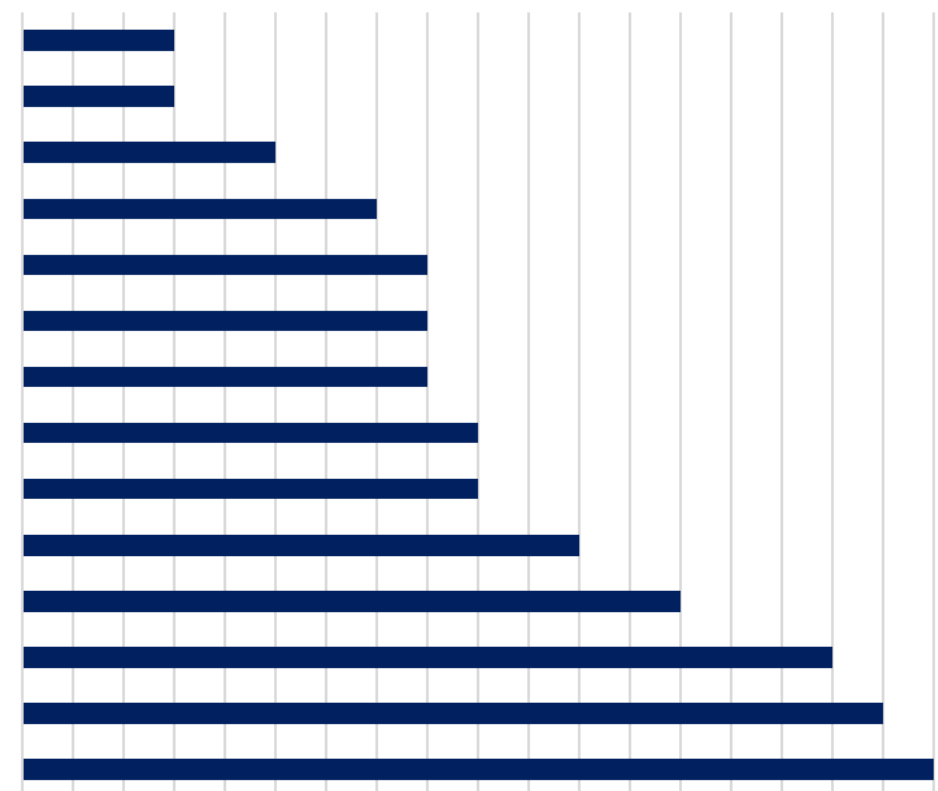

$\begin{array}{lllllllllllllllllll}0 & 1 & 2 & 3 & 4 & 5 & 6 & 7 & 8 & 9 & 10 & 11 & 12 & 13 & 14 & 15 & 16 & 17 & 18\end{array}$ Number of cats affected 
Figure 2. Gross lesions observed in cats with feline infectious peritonitis. There is unilateral anterior uveitis in the left eye and right unilateral mydriasis (A); severe accumulation of peritoneal serofibrinous effusion, with multiple pyogranulomas at the epiploon and serosal surface (arrow-heads) of the liver (B). Brain; the leptomeninges of the cerebrum are thickened (arrows) by pyogranulomatous inflammation exudate (C). Multifocal to coalescing granulomas are easily identified at the serosal surface of the intestines (D). Cross section of a kidney; the renal cortex is severely damaged due to multifocal to coalescing, granulomas $(0.1-1 \mathrm{~cm}$ in diameter), that extended into the underlying parenchyma (E). Liver; multifocal to coalescing granulomas $(0.5-1 \mathrm{~cm}$ in diameter) are observed at the serosal surface of the liver (F). Scale in centimeters.

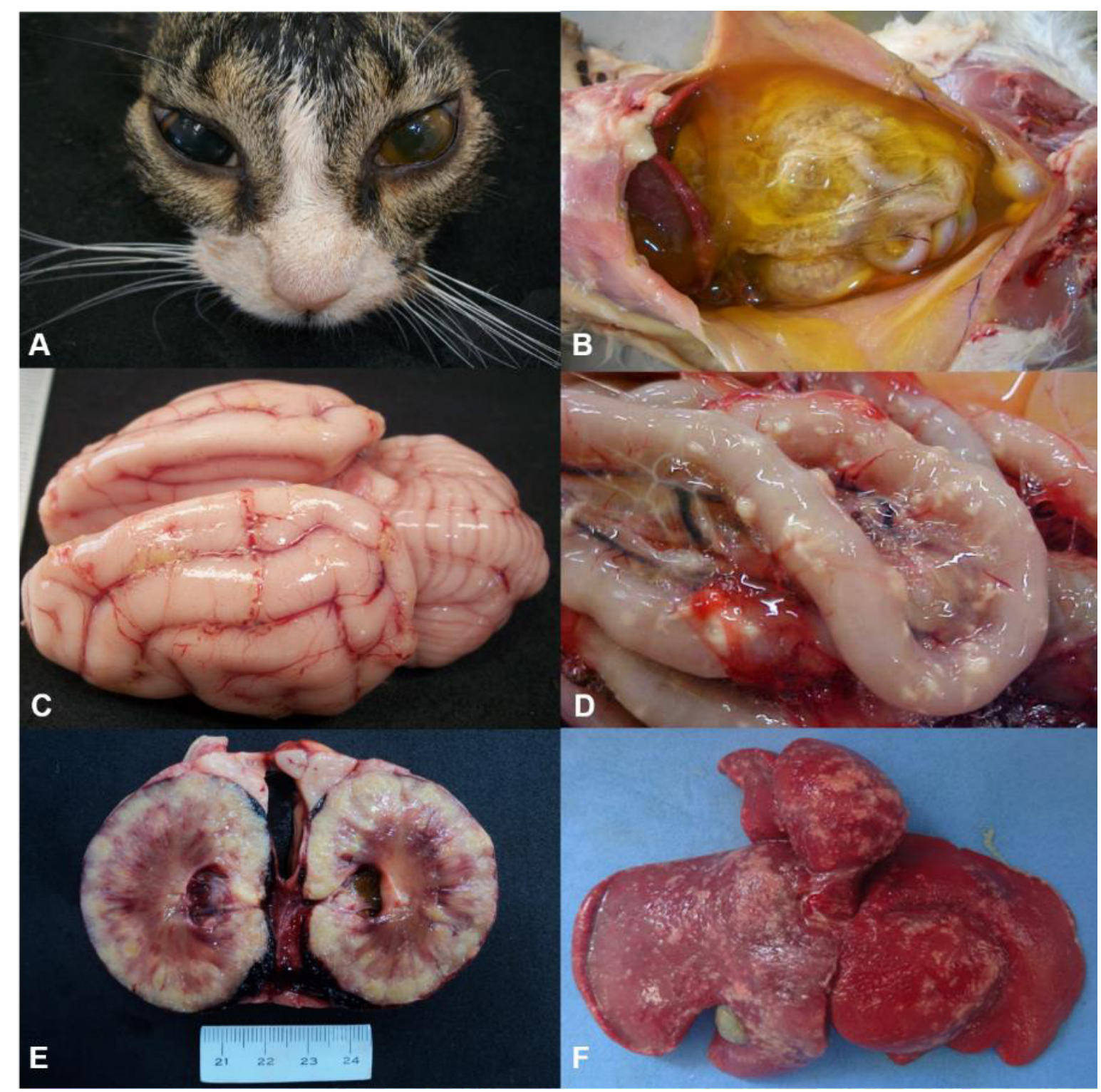


Figure 3. Histopathological findings observed in cats with FIP. Kidney, observe severe pyogranulomatous nephritis intermingled with multifocal to coalescent areas of coagulative necrosis (A). Liver, there is severe multifocal to coalescing necrotizing hepatitis (B). Brain, the leptomeninges were severely thickened due to severe infiltration of degenerated neutrophils, macrophages, and lymphocytes; observe the prominent area $(*)$ of coagulative necrosis $(\mathrm{C})$. Brain, pyogranulomatous phlebitis, chronic, focal, moderate with fibrinoid thrombus (D). Hematoxylin and Eosin stain; bar, A and B, $200 \mu \mathrm{m} ; \mathrm{C}, 100 \mu \mathrm{m}$; and D $50 \mu \mathrm{m}$.

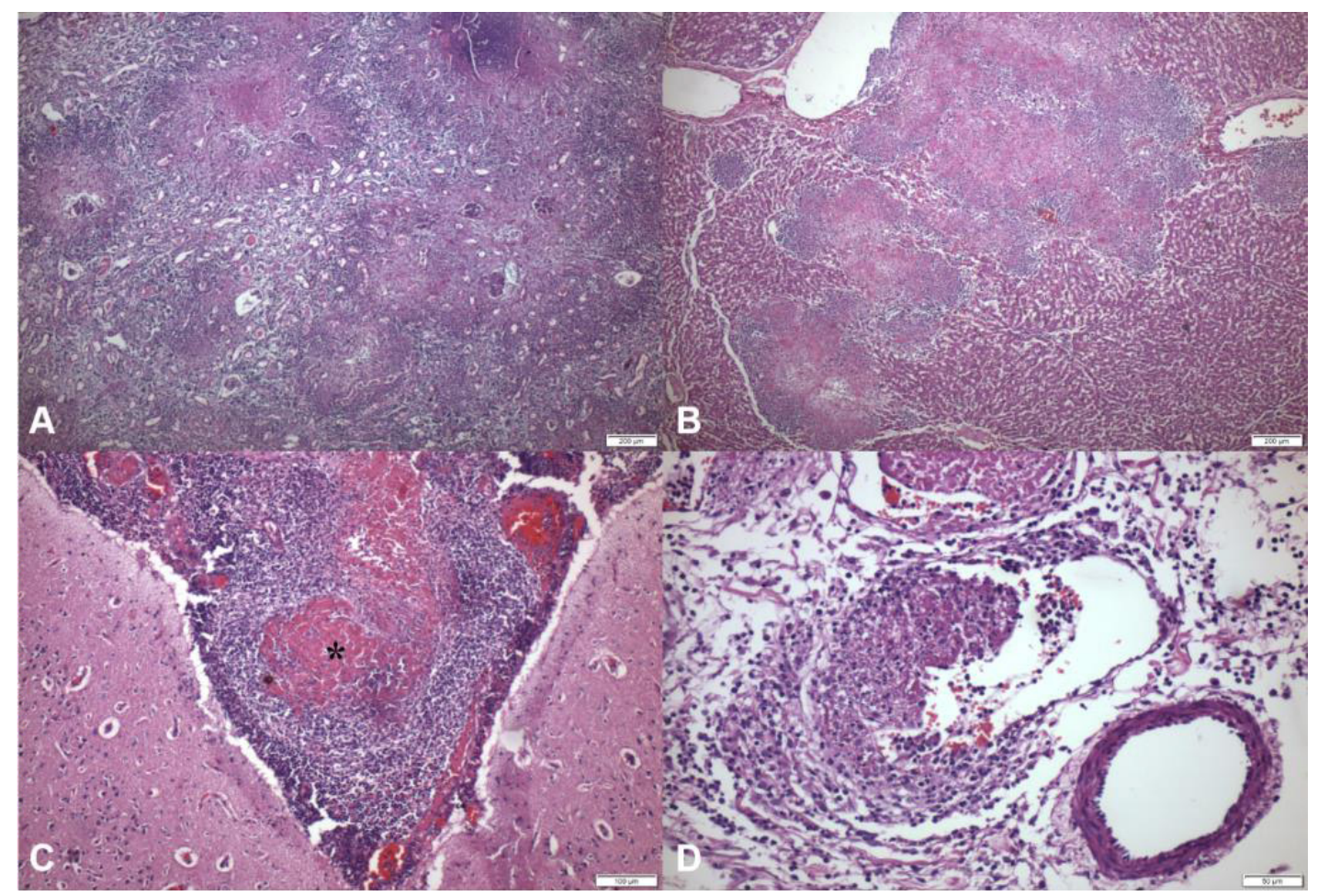

Lesional score of the kidney, brain, and liver of cats with FIP

As indicated previously, only the kidney, brain, and liver were used to estimate the degree of tissue destruction in each organ. The lesions observed in these organs, varied between mild to severe (Figure 3), with all organs attaining a maximum of 48 points. However, when the lesional score attributed to the organs evaluated were compared (Figure 4), FIP-associated renal damage due to coagulative necrosis, granulomas and vasculitis were more frequently observed, more intense and extensive, and significantly different from those that occurred in the brain $(P=0.00005)$ and liver $(P=$ $0.011)$. Although there was no statistical difference in intensity and severity of the cerebral and hepatic lesions observed during this study, FIP-induced neurological lesions were more severe when compared to those of the liver. 
Figure 4. Lesional score in organs infected with FIP. Standard errors of the mean are represented by vertical bars. ${ }^{\text {ab }}$ Values with different letters were significantly different $* \mathrm{P}=0.011$. Tukey test.

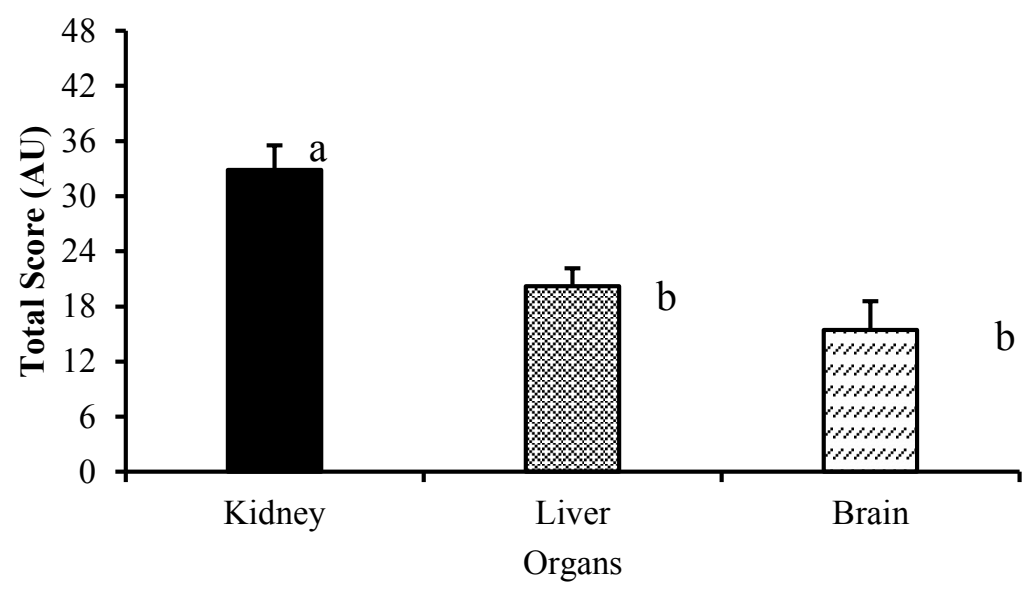

\section{Discussion}

The pathological alterations observed during this investigations are similar to those described in cases of FIP (HARTMANN, 2005; NORRIS et al., 2005; PEDERSEN, 2009; PEDERSEN et al., 2015), considering that a definitive diagnostic of FIP is based on the histopathologic evaluation of the tissues of the affected cat (DRECHSLER et al., 2011). Most organs evaluated during this investigation had some degree of pyogranulomatous inflammatory reaction with an associated vasculitis; pyogranulomatous inflammation and vasculitis are the hallmarks FIP (KIPAR et al., 2005; PEDERSEN, 2009; DRECHSLER et al., 2011; PEDERSEN et al., 2015). Pyogranulomas in effusive FIP were frequently observed at the serous surfaces of abdominal organs during this study; similar findings were described (KIPAR et al., 2005; ADDIE et al., 2009; PEDERSEN, 2009; DRECHSLER et al., 2011). Alternatively, pyogranulomas in noneffusive FIP was predominantly diagnosed at the renal cortex; these findings are in accord with previous descriptions (KIPAR et al., 2005; ADDIE et al., 2009; DRECHSLER et al., 2011).

The evaluation of the lesional score for FIP revealed that the kidney was more severely affected when compared to the lesions observed in the brain and liver. As far as the authors are aware, a lesional score was never provided to estimate the intensity of tissue destruction in FIP. Histopathological lesions observed in the kidneys of all cats evaluated, suggest that this organ is the most susceptible to develop lesions associated with FIP, particularly in cats that are less than one-year-old. Although the reason(s) for the predominance of FIP-associated renal lesions is unclear, several factors can be considered as contributory towards the development of these alterations. The kidney is the organ that is more frequently affected in FIP (BERG et al., 2005; ADDIE et al., 2009; PEDERSEN, 2009; KIPAR; MELI, 2014), and retrospective studies have shown that a large percentage of cats have FIP-associated renal disease (OLIVEIRA et al., 2003; NORRIS et al., 2005); these findings are in accordance with the results of our investigation. The kidney has a single circulatory system, receives $20 \%$ of the cardiac output, is composed of two distinct capillary beds (glomerular and peritubular capillary network), with a complex array of afferent arterioles, resulting in a blood flow that is approximately 40 times more elevated than the other organs (BLANTZ; GABBAI, 2005). Moreover, vasculitis in FIP seems to affect predominantly small to medium-sized veins (KIPAR 
et al., 2005; PEDERSEN, 2009) particularly of the renal cortex leptomeninges, lung, and liver (KIPAR et al., 2005). Collectively, these factors make the kidney highly susceptible to vascular alterations and might explain the predominance of renal destruction observed during this investigation.

Cats that were less than one-year-old were the most significantly (73.7\%) FIP-affected age group; this result is in accordance with the fact that cats between 4 to 16 months of age are more frequently affected (HARTMANN, 2005; PEDERSEN, 2009), confirming that younger cats are more susceptible to FIP than their older counterparts. Stress is known to suppress the immune system (RIEMER et al., 2016), the risk of developing FIP is higher in young cats is due to the immaturity of their immune system and the exposure to various stressful events, such as weaning, castration and vaccination (HARTMANN, 2005; PEDERSEN, 2009; 2014).

The prevalence of FIP $(3.7 \% ; 19 / 520)$ identified during this investigation was similar to that observed in other reports from Brazil, where a prevalence of $1.12 \%(49 / 4,357)$ was described in São Paulo (SANTOS et al., 2013) and 2.03\% $(13 / 638)$ in Rio Grande do Sul (OLIVEIRA et al., 2003). Epidemiological studies done in other countries have revealed prevalence levels of FIP that varied between $0.52 \%(60 / 11,535)$ in Raleigh, North Carolina, USA (PESTEANU-SOMOGYI et al., 2006), and in 1.41\% $(231 / 16,275)$ from Munich, Germany (RIEMER et al., 2016). The prevalence levels identified in Brazil might be related to the fact that cat owners do not frequently submit their pets for necropsy evaluation at veterinary hospitals due to financial constraints (SANTOS et al., 2013), which probably underestimates the prevalence of this disease.

There was no statistical difference $(P=0.822)$ between the gender of cats with FIP; similar results were observed in North Carolina, USA (PESTEANU-SOMOGYI et al., 2006), where from a population of 11,475 cats, only 60 were infected $(P=0.425 ; 53.6 \%$ female, $59.6 \%$ male with FIP). Alternatively, male cats with FIP were overrepresented in an epidemiological study from Australia (NORRIS et al., 2005). In our study, no statistical difference $(P=0.437)$ was observed when mixed-breed cats with FIP were compared with their pure breed counterparts. However, purebred Abyssinians, Bengal, Himalayan, Ragdoll (PESTEANU-SOMOGYI et al., 2006), and Burmese (NORRIS et al., 2005; PESTEANUSOMOGYI et al., 2006) cats were considered as having a more elevated risk to develop FIP. In addition, domestic short hair cats were also over represented in a German study (RIEMER et al., 2016). Consequently, breed differences relative to the occurrence of FIP may be directly related to the population of cats attended at institutions and/or clinics within a geographical region.

In conclusion, the results of this study have demonstrated that the incidence and prevalence of FIP in Southern Brazil was more elevated in cats that were less than one-year-old, with no predilection for sex and breed. The lesional score system suggested that the kidney was the organ most frequently and severely affected. Moreover, pyogranulomatous nephritis with associated vasculitis was the histopathological lesion observed in all cats with FIP. In addition, coagulative necrosis seems to be one of the most important histopathological alterations associated with tissue destruction in FIP and should be included in the diagnosis of this disease.

\section{Acknowledgments}

The authors are thankful to Dr. Juliana Rubira Gerez for assistance with the processing of the statistical data. T.E.S. Oliveira and S.A. Headley are recipients of The National Counsel for Scientific and Technological Development (CNPq; Brazil) Fellowships. 


\section{Conflict of interests}

The author(s) declared no potential conflicts of interest with respect to the research, authorship, and/or publication of this article.

\section{References}

ADDIE, D. Feline coronavirus infections. In: GREENE, C. E. (Ed.). Infections disease of the dog and cat. $4^{\text {th }} \mathrm{ed}$. Missouri: Elsevier, 2012. v. 4, cap. 10, p. 92-108.

ADDIE, D.; BELAK, S.; BOUCRAUT-BARALON, C.; EGBERINK, H.; FRYMUS, T.; GRUFFYDD-JONES, T.; HARTMANN, K.; HOSIE, M. J.; LLORET, A.; LUTZ, H.; MARSILIO, F.; PENNISI, M. G.; RADFORD, A. D.; THIRY, E.; TRUYEN, U.; HORZINEK, M. C. Feline infectious peritonitis. $\mathrm{ABCD}$ guidelines on prevention and management. Journal of Feline Medicine and Surgery, London, v. 11, n. 7, p. 594-604, 2009.

BELL, E. T.; TORIBIO, J. A.; WHITE, J. D.; MALIK, R.; NORRIS, J. M. Seroprevalence study of feline coronavirus in owned and feral cats in Sydney, Australia. Australian Veterinary Journal, New South Wales, v. 84, n. 3, p. 74-81, 2006.

BENETKA, V.; KÜBBER-HEISS, A.; KOLODZIEJEK, J.; NOWOTNY, N.; HOFMANN-PARISOT, M.; MÖSTL, K. Prevalence of feline coronavirus types I and II in cats with histopathologically verified feline infectious peritonitis. Veterinary Microbiology, Amsterdam, v. 99, n. 1, p. 31-42, 2004.

BERG, A. L.; EKMAN, K.; BELÁK, S.; BERG, M. Cellular composition and interferon- $\gamma$ expression of the local inflammatory response in feline infectious peritonitis (FIP). Veterinary Microbiology, Amsterdam, v. 111, n. 1-2, p. 15-23, 2005.

BLANTZ, R. C.; GABBAI, F. B. Physiology of the renal circulation. In: GINĖS, P.; ARROYO, V.; RODÉS, J.; SCHRIE, R. (Ed.). Ascites and renal dysfunction in liver disease: pathogenesis, diagnosis, and treatment. Malden: Blackwell Publishing Ltd., 2005. cap. 2, p. 15-28.

DRECHSLER, Y.; ALCARAZ, A.; BOSSONG, F. J.; COLLISSON, E. W.; DINIZ, P. P. Feline coronavirus in multicat environments. The Veterinary Clinics of North America. Small Animal Practice, Philadelphia, v. 41, n. 6, p. 1133-1169, 2011.

GRENIER，B.; LOUREIRO-BRACARENSE，A. P.; LUCIOLI, J.; PACHECO, G. D.; COSSALTER, A. M.; MOLL, W. D.; SCHATZMAYR, G.; OSWALD, I. P. Individual and combined effects of subclinical doses of deoxynivalenol and fumonisins in piglets. Molecular Nutrition \& Food Research, Weinheim, v. 55, n. 5, p. 761-771, 2011.

HARTMANN, K. Feline infectious peritonitis. The Veterinary Clinics of North America. Small Animal Practice, Philadelphia, v. 35, n. 1, p. 39-79, 2005.

KIPAR, A.; MAY, H.; MENGER, S.; WEBER, M.; LEUKERT, W.; REINACHER, M. Morphologic features and development of granulomatous vasculitis in feline infectious peritonitis. Veterinary Pathology, New York, v. 42, n. 3, p. 321-330, 2005.

KIPAR, A.; MELI, M. L. Feline infectious peritonitis: still an enigma? Veterinary Pathology, New York, v. 51, n. 2, p. 505-526, 2014.

NORRIS, J. M.; BOSWARD, K. L.; WHITE, J. D.; BARAL, R. M.; CATT, M. J.; MALIK, R. Clinicopathological findings associated with feline infectious peritonitis in Sydney, Australia: 42 cases (1990-2002). Australian Veterinary Journal, New South Wales, v. 83, n. 11, p. 666-673, 2005.

OLIVEIRA, F. N.; RAFFI, M. B.; SOUZA, T. M.; BARROS, C. S. L. Peritonite infecciosa felina: 13 casos. Ciência Rural, Santa Maria, v. 33, n. 5, p. 905-911, 2003.

PEDERSEN, N. C. A review of feline infectious peritonitis virus infection: 1963-2008. Journal of Feline Medicine and Surgery, London, v. 11, n. 4, p. 225-258, 2009.

An update on feline infectious peritonitis: virology and immunopathogenesis. Veterinary Journal, New York, v. 201, n. 2, p. 123-132, 2014.

PEDERSEN, N. C.; ECKSTRAND, C.; LIU, H.; LEUTENEGGER, C.; MURPHY, B. Levels of feline infectious peritonitis virus in blood, effusions, and various tissues and the role of lymphopenia in disease outcome following experimental infection. Veterinary Microbiology, Amsterdam, v. 175, n. 2-4, p. 157-166, 2015.

PESTEANU-SOMOGYI, L. D.; RADZAI, C.; PRESSLER, B. M. Prevalence of feline infectious peritonitis in specific cat breeds. Journal of Feline Medicine and Surgery, London, v. 8, n. 1, p. 1-5, 2006.

RIEMER, F.; KUEHNER, K. A.; RITZ, S.; SAUTERLOUIS, C.; HARTMANN, K. Clinical and laboratory features of cats with feline infectious peritonitis - a retrospective study of 231 confirmed cases (2000-2010). Journal of Feline Medicine and Surgery, London, v. 18, n. 4, p. 348-356, 2016. 
SANTOS, D. L.; LUCAS, R.; LALLO, M. A. Epidemiologia da imunodeficiência viral, leucemia viral e peritonite infecciosa em felinos procedentes de um hospital veterinário. Revista Acadêmica, Ciências Agrárias e Ambiental, Curitiba, v. 11, n. 2, p. 161-168, 2013.

SOMA, T.; WADA, M.; TAHARAGUCHI, S.; TAJIMA, T. Detection of ascitic feline coronavirus RNA from cats with clinically suspected feline infectious peritonitis. Journal of Veterinary Medical Science, Tokyo, v. 75, n. 10, p. 1389-1382, 2013.
TANAKA, Y.; SASAKI, T.; MATSUDA, R.; UEMATSU, Y.; YAMAGUCHI, T. Molecular epidemiological study of feline coronavirus strains in Japan using RTPCR targeting nsp14 gene. BMC Veterinary Research, London, v. 11, n. 1, p. 57, 2015.

TEKELIOGLU, B. K.; BERRIATUA, E.; TURAN, N.; HELPS, C. R.; KOCAK, M.; YILMAZ, H. A retrospective clinical and epidemiological study on feline coronavirus (FCoV) in cats in Istanbul, Turkey. Preventive Veterinary Medicine, Amsterdam, v. 119, n. 1-2, p. 41-47, 2015.

WORTHING, K. A.; WIGNEY, D. I.; DHAND, N. K.; FAWCETT, A.; MCDONAGH, P.; MALIK, R.; NORRIS, J. M. Risk factors for feline infectious peritonitis in Australian cats. Journal of Feline Medicine and Surgery, London, v. 14, n. 6, p. 405-412, 2012. 
